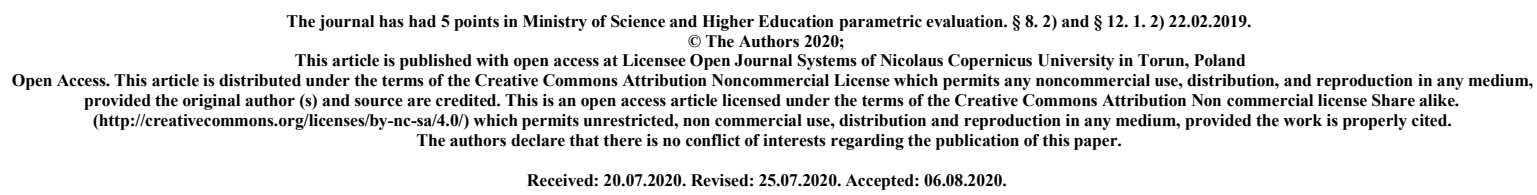

\title{
Effect of subacute poisoning with selected pyrethroids on fresh spatial memory and movement activity in mice
}

\author{
Michał Konopelko, Barbara Nieradko-Iwanicka
}

Medical University of Lublin, Chair and Department of Hygiene, Radziwillowska 11 Street, 20-080 Lublin;

Correspondence: Barbara Nieradko-Iwanicka

e-mail barbara.nieradko-iwanicka@umlub.pl

\begin{abstract}
Introduction. Pyrethroids are commonly used in agriculture and for indoor insect control. They act as neurotoxins mainly via sodium channels in neurons. People can be exposed to traces of these xenobiotics dermally, with food, at home or at workplace. Three pyrethroids: cypermethrin, lambdacyhalothrin, and betacyfluthrin were chosen for modelling subacute oral poisoning in mice.

The aim of the study was to assess if 7-day exposure to $0.1 \mathrm{LD}_{50}$ of each compound could impair memory and motor activity in mice.

Materials and methods. A total of 64 mice were divided into 8 groups of 8 animals: females controls, males controls, females receiving cypermethrin, males receiving cypermethrin, females receiving lambdacyhalothrin, males receiving lambdacyhalothrin, females receiving betacyfluthrin, males receiving betacyfluthrin. They were given $0.1 \mathrm{LD}_{50}$ of a pyrethroid dissolved in canola oil by gavage daily for 7 days. They were tested in a Y-maze on day 1 and 7.
\end{abstract}


Results. Subacute poisoning with betacyfluthrin significantly reduces locomotor activity in females on day 1 and in both genders on day 7 without effect on fresh spatial memory. Conclusion. Betacyfluthrin is the most harmful of the tested pesticides.

Keywords: Cypermethrin; lambdacyhalothrin; betacyfluthrin; neurotoxicology

\section{Introduction}

Pyrethroids are commonly used in agriculture and for indoor insect control $(1,2)$. They act as neurotoxins mainly via sodium channels in neurons (3). Pyrethroids delay the closure of voltage-sensitive sodium channels and protracted sodium influx lowers the action potential threshold and causes repetitive firing. This is the mechanism causing paraesthesiae in pyrethroid poisoning, especially after dermal exposure (4). According to their structure they are classified as type I (devoid of cyano-moiety) and II (have an alpha-cyano moiety at the alpha-position (2). Human exposure to these xenobiotics can be dermal or oral. Three type II pyrethroids: cypermethrin, lambdacyhalothrin, and betacyfluthrin were chosen for modelling subacute oral poisoning in mammals.

Cypermethrin is used to control moth pests of cotton, insect pests on fruits and vegetable crops, as well as for pest control inside stores, industrial buildings, apartments, houses, labs buses, trains, ships and aircrafts (5). It can be used as insect repellent for horses (6). It is available in the form of emulsions and powders (5). Cypermethrin oral $\mathrm{LD}_{50}$ for mice is $82-$ $779 \mathrm{mg} / \mathrm{kg}$ depending on the ratio of cis/trans-isomers present (7)]. According to our previous experience cypermethrin $\mathrm{LD}_{50}$ is $120 \mathrm{mg} / \mathrm{kg}$.

Lambdacyhalothrin is used for insect control indoors at homes, in hospitals, greenhouses, to protect ornament plants, for lawn protection, as insect repellent for cattle, and for termite treatment (8). Oral LD $\mathrm{LD}_{50}$ in mice $19.9 \mathrm{mg} / \mathrm{kg}(8)$.

Betacyfluthrin is a moderately toxic pyrethroid. It is available in the form of emulsifiable concentrate and aqueous concentrate (9). It is used in agriculture and viticulture, against locusts and grasshoppers (10). Oral LD $\mathrm{LD}_{50}$ in male mice is $91 \mathrm{mg} / \mathrm{kg}$ and for female $165 \mathrm{mg} / \mathrm{kg}$ body weight (10). For cyfluthrin oral $\mathrm{LD}_{50}$ in mice is $291-609 \mathrm{mg} / \mathrm{kg}(9)$. Our previous experience indicated that betacyfluthrin's $\mathrm{LD}_{50}$ is $200 \mathrm{mg} / \mathrm{kg}$.

The aim of the study was to assess if doses near $0.1 \mathrm{LD}_{50}$ of each of the tested compounds could impair memory and motor activity in mice.

\section{Materials and Methods}

The study project was accepted by The Local Ethical Committee in Lublin, Poland (permission $\mathrm{Nr}$ 69/2015 dated 11.12.2015). Both authors had certificates confirming training for conduction experiments on animals. The experiment was conducted according to European law regulation at the Center for Experimental Medicine at The Medical University of Lublin. There were standard laboratory conditions. Behavioral tests were performed from 9 a.m. till 3.p.m. 
A total of 64 (32 non-gravid females and 32males) Albino Swiss mice weighing 20-25g at the beginning of the experiment were divided into 8 groups of 8 animals:

1. females -controls

2. males-controls

3. females- receiving $12 \mathrm{mg} / \mathrm{kg}$ cypermethrin

4. males -receiving $12 \mathrm{mg} / \mathrm{kg}$ cypermethrin

5. females- receiving $2 \mathrm{mg} / \mathrm{kg}$ lambdacyhalothrin

6. males -receiving $2 \mathrm{mg} / \mathrm{kg}$ lambdacyhalothrin

7. females- receiving $20 \mathrm{mg} / \mathrm{kg}$ betacyfluthrin

8. males -receiving $20 \mathrm{mg} / \mathrm{kg}$ betacyfluthrin

Cypermethrin, lambdacyhalothrin and betacyfluthrin were purchased form Organic Chemistry Institute (Annopol 6, 03-236 Warsaw). They were dissolved in canola oil and administered daily by gavage.

Animas were tested in a $\mathrm{Y}$ maze on day 1 and 7 in order to measure their spontaneous locomotor activity and fresh spatial memory.

Locomotor activity monitoring and fresh spatial memory in a Y-maze started 1hour after the dosing of a pyrethroid and was continued for $8 \mathrm{~min}$. Spontaneous alternation in a Y-maze is a measure of fresh spatial memory. Each mouse was individually placed in the Y-maze. It consists of 3 compartments $10 \times 10 \times 10 \mathrm{~cm}$ joined at the angle of $120^{\circ}$. The maze has no floor. For each mouse a clean sheet of paper was placed underneath in order to prevent odour clues. Alternation (defined as consecutive entries into all 3 sections without repetitions) was scored. The percent alternation was calculated as the ratio of actual possible alternations. The ability to alternate requires that the mice remember which sections have previously been visited. The number of arm entries is also a measure of locomotor activity.

The results were analyzed with IBM SPSS Statistics (v. 21).

\section{Results}

Measuring locomotor activity in a Y-maze on day 1 (mean \pm SD) control females had $55 \pm 81$, males $\quad 38 \pm 8.2$ arm entries, cypermethrin-exposed females had $45.38 \pm 12.74$ arm entries, cypermethrin-exposed males $36.75 \pm 6.96$, lambdacyhalothrin-exposed females $53.88 \pm 13.59$, lambdacyhalothrin-exposed males $34.75 \pm 7.29$, betacyfluthrin-exposed females $27.25 \pm 10$ ( $\mathrm{p}<0.05$ vs controls), males 29.38 \pm 9.88 . On day 7: female controls $48 \pm 7.9$, male controls $45 \pm 10.1$, females intoxicated with cypertmethrin $34.5 \pm 19.73$, males intoxicated with cypertmethrin $32.75 \pm 10.54$, females intoxicated with lambdacyhalothrin $46.63 \pm 23.22$, males intoxicated with lambdacyhalothrin $35.13 \pm 3.6$, females intoxicated with betacyfluthrin $29.5 \pm 10.66(\mathrm{p}<0.05 v s$ controls $)$, males intoxicated with betacyfluthrin $21.12 \pm 10.58(\mathrm{p}<0,05$ vs controls).

The number of logical alternation in the $\mathrm{Y}$ maze on day 1 was (mean $\pm \mathrm{SD}$ ): for female controls $71 \pm 4.12$, male controls $69 \pm 9.50$, females exposed to cypermethrin $62.29 \pm 8.48$, males exposed to cypermethrin $69.43 \pm 9.85$, females exposed to lambdacyhalothrin $60.81 \pm 15.06$, males exposed to lambdacyhaothrin $60.98 \pm 16.72$, females exposed to betacyfluthrin $64.84 \pm 16.72$, males exposed to betacyfluthrin $62.14 \pm 15.28$. On day 7 the numbers of logical alternation was for female controls $65.80 \pm 11$, male controls $66.32 \pm 80$, females exposed to cypermethrin was $59,54 \pm 10,95$, males exposed to cypermethrin was $62.75 \pm 10.96$, females 
exposed to lambdacyhaothrin was $54.16 \pm 9.33$, males exposed to lambdacyhaothrin was $68.34 \pm 11.52$, females exposed to betacyfluthrin was $65.48 \pm 18.07$, males exposed to betacyfluthrin was $65.14 \pm 11.84$.

\section{Discussion}

Our results show that cypermethrin, lambdacyhalothrin, and betacyfluthrin affect locomotor activity in mice. The effect is best visible after use of $0.1 \mathrm{LD}_{50}$ betacyfluthrin. Male mice are more sensitive to the used pyrethroids than females. The neurotoxic effects in animals vary depending on the compound used and the proportion of isomers. Cypermethrin is a mixture of eight different isomers with different properties (5). Cyhalothrin is a mixture of four isomers. Two of them compose lambda-cyhalothrin (1), 12,13]. Beta-cyfluthrin is a mixture of four diastereoisomers (10).

Studies of neurotoxicity of pyrethroids were conducted previously. Wolansky et al. assessed the influence of a mixture of 11 pyrethroids (including cypermethrin, lambdacyhalothrin, and betacyfluthrin) administered orally on motor activity in rats. They confirmed additive effect of pyrethroids on rat behaviour (14). In our experiment cypermethrin and lambdacyhalothrin just slightly more decreased fresh spatial memory on day7 if compared with day 1 . Betacylfluthrin significantly decreased locomotor activity on day 7 if compared to controls in males and females. On day 1 the locomotion reducing effect was significant in females.

Motor activity is often used in experiments on neurotoxicity as it is a valid test method routinely used in acute and subchronic regulatory neurotoxicity studies (15). Crofton and Reiter confirmed that 30-day exposure of rats to deltamethrin or cismethrin reduces their locomotor activity (16). In the study of Singh et al. authors showed that type II pyrethroid cypermethrin acts not only via influence on sodium channel, but also modulates chloride channels, voltage-gated calcium and potassium channels, alters the activity of glutamate and acetylcholine receptors and adenosine triphosphatases inducing DNA damage and oxidative stress in the neuronal cells. Cypermethrin also modulates the level of neurotransmitters, including gamma-aminobutyric acid (GABA) and dopamine (17). The reduction in locomotor activity in our experiment especially after 7-day exposure to betacyfluthrin is probably also an effect of the pyrethroid interaction with GABA receptors.

For us the experiment is also a mode of possible human exposure to pyrethroids. There is a report that one man died after eating a meal cooked in a $10 \%$ cypermethrin mistakenly used for cooking oil. After eating it he had nausea, vomiting, stomach pain, diarrhea, convulsions, unconsciousness and coma. His family members had milder symptoms of intoxication (18). Sirisha et al. published a case report of a man who consumed a large dose of lambdacyhalothrin with a suicidal intent, had excessive salivation, fatigue, cough and abdominal pain, but after receiving $4 \mathrm{mg}$ of dexamethasone to prevent respiratory inflammation and $40 \mathrm{mg}$ of pantoprazole the patient was discharged in a good condition (18). This must be due to the fact that pyrethroids are 2250 times more toxic to insects than mammals (19). Sodium channels in insects are much more sensitive to pyrethroids than in humans. Additionally insects have smaller body size and lower body temperature. Humans are able to maintain constant internal body temperature and fast metabolize xenobiotics in the liver to relatively non-toxic metabolites (19). 
Even though birds are homeothermic, like humans, they have various sensitivity to pyrethroids. Canaries are the most sensitive to betacyfluthrin (20).

\section{Conclusions}

Betacyfluthrin administered at the dose of $0.1 \mathrm{LD}_{50}$ shows the greatest neurotoxic effects of tested pyrethroids.

Authors declare no conflict of interest. The research involved animals. The study project was accepted by The Local Ethical Committee in Lublin, Poland. No human participants were involved in the study. Informed consent- not applicable.

\section{References}

1. Chrustek A., Hołyńska-Iwan I ; Dziembowska I., Bogusiewicz J., Wróblewski M., Cwynar A., Olszewska-Słonina D.: Current Research on the Safety of Pyrethroids Used as Insecticides. Medicina (Kaunas) 2018, 54(4),61.doi: 10.3390/medicina54040061.

2. Matsuo N.: Discovery and Development of Pyrethroid Insecticides. Proc Jpn Acad Ser B Phys Biol Sci. 2019,95(7),378-400.doi: 10.2183/pjab.95.027.

3. Field L.M., Emyr Davies T.G., O'Reilly A.O., Williamson M.S., Wallace B.A.: Voltage-gated sodium channels as targets for pyrethroid insecticides. Eur Biophys J. 2017,46(7),675-679. doi: 10.1007/s00249-016-1195-1.

4. Perkins A., Walters F., Sievert J., Rhodes B., Morrissey B., Karr C.J. : Home Use of a Pyrethroid-Containing Pesticide and Facial Paresthesia in a Toddler: A Case Report. Int J Environ Res Public Health. 2016, 13(8), 829. doi: 10.3390/ijerph13080829.

5. Zortéa T., Baretta D., Maccari A.P., Segat J.C., Boiago E.S., Sousa J.P., Da Silva A.S.: Influence of Cypermethrin on Avoidance Behavior, Survival and Reproduction of Folsomia Candida in Soil. Chemosphere. 2015, 122, 94-98. doi:1016/j.chemosphere.2014.11.018.

6. Page P., Ganswindt A , Schoeman J , Venter G , Guthrie A.: The effect of alphacypermethrin-treated mesh protection against African horse sickness virus vectors on jet stall microclimate, clinical variables and faecal glucocorticoid metabolites of horses. BMC Vet Res. 2017,13(1),283. doi: 10.1186/s12917-017-1198-x.

7. Belay Y .T.: Study of the principles in the first phase of experimental pharmacology: the basic step with assumption hypothesis. BMC Pharmacol Toxicol. 2019,20(1),30. doi: 10.1186/s40360-019-0306-x.PMID: 31113474.

8. $\quad$ Elhalwagy M.E., Abd-Alrahman S.H., Nahas A.A., Ziada R.M., Mohamady A.H.: Hepatopancreatic intoxication of lambda cyhalothrin insecticide on albino rats. Int J Clin Exp Med. 2015, 8(5),7297-305.

9. Extension Toxicology Network. Cyfluthrin http://pmep.cce.cornell.edu/profiles/extoxnet/carbaryl-dicrotophos/cyfluthrin-ext.html Accessed 15.05.2020.

10. Food and Agriculture Organization of the United Nations. BETA-CYFLUTHRIN (1RS, 3RS; 1RS, 3SR)-3-(2,2-dichloro-vinyl)-2,2-dimethylcyclopropane- carboxylic acid (RS)-cyano-(4-fluoro-3- phenoxy-phenyl)-methyl ester. FAO Specifications and evaluations for plant protection products. 2016. 
11. Birolli W.G., Vacondio B., Alvarenga N., Seleghim M.H.R., Porto A.L.M.: Enantioselective biodegradation of the pyrethroid $( \pm$ )-lambda-cyhalothrin by marine-derived fungi. Chemosphere. 2018,197,651-660. doi: 10.1016/j.chemosphere.2018.01.054.

12. Chen S., Deng Y., Chang C., Lee J., Cheng Y., Cui Z., Zhou J., He F., Hu M., Zhang L.H.: Pathway and kinetics of cyhalothrin biodegradation by Bacillus thuringiensis strain ZS19.Sci Rep 2015, 8784, doi: 10.1038/srep08784.

13. Tomar M., Kataria S.K., Kumar A.: Evaluation of Acute toxicity of Lambda Cyhalothrin in Mus musculus L. Indian journal of experimental biology 2015, 53(8),551555.

14. Wolansky M.J., Gennings C., DeVito M.J., Crofton K.M.: Evidence for Dose-Additive Effects of Pyrethroids on Motor Activity in Rats. Environ Health Perspect. 2009, 117(10), $1563-1570$.

15. OECD (Organisation for European Co-operation and Development) Test Guideline 424. OECD Guideline for Testing of Chemicals. Neurotoxicity Study in Rodents. 1997. Accessed 15.05.2020.

16. Crofton K.M.. Reiter L.W.: Effects of two pyrethroid insecticides on motor activity and the acoustic startle response in the rat. Toxicol Appl Pharmacol. 1984;75:318-328.

17. Singh AK, Tiwari MN, Prakash O, Singh MP. A Current Review of CypermethrinInduced Neurotoxicity and Nigrostriatal Dopaminergic Neurodegeneration. Curr Neuropharmacol. 2012, 10(1), 64-71.doi: 10.2174/157015912799362779.

18. Sirisha N., Bhavani M., Rudra J.T., Rajavardhana T., Kumar P., Ushanandini T., Reddenna L., Sreedhar V.: Lambda-Cyhalothrin: An Unusual Pyrethroid Poisoning. EAS Journal of Pharmacy and Pharmacology.2019, 1(1),5-6.

19. Abreu-Villaça Y., Levin E.D.: Developmental neurotoxicity of succeeding generations of insecticides. Environ Int. 2017, 99, 55-77, doi: 10.1016/j.envint.2016.11.019.

20. Etterson M., Garber K., Odenkirchen E.: Mechanistic modeling of insecticide risks to breeding birds in North American agroecosystems. PLoS One. 2017,12(5),e0176998. doi: 10.1371/journal.pone.0176998. 